University of Nebraska - Lincoln

DigitalCommons@University of Nebraska - Lincoln

Publications, Agencies and Staff of the U.S.

Department of Commerce

U.S. Department of Commerce

2004

\title{
Lopsided fish in the Snake River Basin - fluctuating asymmetry as a way of assessing impact of hatchery supplementation in chinook salmon, Oncorhynchus tshawytscha
}

\author{
Orlay Johnson \\ Northwest Fisheries Science Center, orlay.johnson@noaa.gov \\ Kathleen Neely \\ Northwest Fisheries Science Center, kathleen.neely@noaa.gov \\ Robin Waples \\ NOAA, robin.waples@noaa.gov
}

Follow this and additional works at: https://digitalcommons.unl.edu/usdeptcommercepub

Johnson, Orlay; Neely, Kathleen; and Waples, Robin, "Lopsided fish in the Snake River Basin - fluctuating asymmetry as a way of assessing impact of hatchery supplementation in chinook salmon, Oncorhynchus tshawytscha" (2004). Publications, Agencies and Staff of the U.S. Department of Commerce. 449.

https://digitalcommons.unl.edu/usdeptcommercepub/449

This Article is brought to you for free and open access by the U.S. Department of Commerce at DigitalCommons@University of Nebraska - Lincoln. It has been accepted for inclusion in Publications, Agencies and Staff of the U.S. Department of Commerce by an authorized administrator of DigitalCommons@University of Nebraska - Lincoln. 
Environmental Biology of Fishes 69: 379-393, 2004

(c) 2004 Kluwer Academic Publishers. Printed in the Netherlands.

This article is a U.S. government work, and is not subject to copyright in the United States.

\title{
Lopsided fish in the Snake River Basin - fluctuating asymmetry as a way of assessing impact of hatchery supplementation in chinook salmon, Oncorhynchus tshawytscha
}

\author{
Orlay Johnson, Kathleen Neely \& Robin Waples \\ National Marine Fisheries Service, Northwest Fisheries Science Center, 2725 Montlake Blvd. East, \\ Seattle, WA 98112, U.S.A. (e-mail: orlay.johnson@noaa.gov)
}

Received 17 April $2003 \quad$ Accepted 19 April 2003

Key words: developmental instability, Pacific salmon, meristics

\section{Synopsis}

The use of developmental instability (an individual's failure to produce a consistent phenotype in a given environment) was evaluated to detect the effects of outplanting hatchery fish on wild salmon. Juvenile chinook salmon were collected in 1989, 1990, and 1991 from five drainages in the Snake River Basin. In each drainage we attempted to collect fish from streams with no hatchery supplementation (wild), naturally spawning fish from streams with hatchery supplementation (natural), and fish collected at a hatchery. Forty fish were collected per site and the number of elements in bilateral characters were counted on each side of the fish. Indices of fluctuating asymmetry (FA), a measure of minor, random deviations in perfect symmetry of bilateral counts, were calculated as an estimator of developmental instability. Analysis of character counts from seven paired characters revealed normal distributions. Only one of the characters displayed counts that were statistically larger on one side than the other, indicating that directional asymmetry (DA) or antisymmetry was not a major bias of FA. However, the means of all individual characters revealed a non-statistically significant left side bias. We analyzed our data using two indices of FA (FA1 and FA5) with different levels of sensitivity to DA. Differences in both FA indices were found among years, with collection sites in 1989 having significantly larger FA values than in 1991 (FA p < 0.01). Levels of FA among wild, natural, and hatchery fish were comparatively small (FA1 $\mathrm{p}=0.17$ ). This suggests developmental conditions were different in the first year of the study than in the last. The cause of these differences may be linked to either genetic or environmental variation or to gene-environment interactions, but the general population declines of salmon that occurred during this time obscures more specific conclusions.

\section{Introduction}

The abundance of most naturally spawning Pacific salmon species has been substantially below historical levels in recent years (Nehlsen et al. 1991, McClure et al. 2003). The cause of these low levels has been attributed to a multitude of impacts such as poor forestry and agriculture practices, overgrazing, over-fishing, industrialization, urbanization, dams, hatcheries, variation in ocean conditions, and global climate change (Magnuson 1996).

To stem the decline in the Columbia River Basin, a wide variety of recovery and restoration programs have been proposed, including hatchery supplementation of wild populations. Hatchery supplementation programs have been evaluated in numerous studies in order to improve their effectiveness (Allendorf \& Ryman 1987, Reisenbichler \& Rubin 1999, Waples \& Drake 2003), but there are still substantial gaps in our knowledge of how to supplement natural populations effectively. Among the most important factors to consider are the genetic consequences of releasing hatchery-reared fish into the wild (e.g., Waples 1991, Hindar et al. 1991, Cuenco et al. 1993, Campton 1995, Lynch \& O'Hely 2001, Ford 2002) and the resulting genetic introgression that presumably occurs with wild populations. 
This is an important consideration because the genetic makeup of native wild stocks has presumably been shaped by many years of adaptation to local conditions (Ricker 1972, Taylor 1991), and transplanted fish (especially if not of local origin) may be less well suited to local conditions (Reisenbichler \& Rubin 1999).

Assessment of changes in the population structure or stability resulting from these population declines and recovery efforts have been widely acknowledged as both important and difficult (Magnuson 1996, Ham \& Pearsons 2000). For thousands of years, salmon have adapted to local conditions (e.g., evolved co-adapted gene complexes) that allow them to home to natal streams and survive in a variety of changing and often harsh conditions. Crosses of genetically distinct parents (intraspecific hybridization) may result in disruption of these adaptive mechanisms, and even small changes in this structure may cause extinctions of locally adapted populations. However, our understanding of what these changes are, or how they occur, are often too little for managers to implement effective remediation action until it is too late (Magnuson 1996, Ham \& Pearsons 2000).

Ecological parameters, such as productivity, survivorships, or fecundity are often used as indicators of population well being. However, these parameters are often lagging indicators of stress, documenting problems that have already occurred $\left(\right.$ Freeman $\left.^{1}\right)$. Estimation of changes in a population's developmental instability has been suggested as a leading indicator of problems that could signal trouble before demographic declines occur (Freeman ${ }^{1}$ ).

Developmental instability represents the inability of an embryo to produce a consistent phenotype in a given environment (Waddington 1957, Møller \& Swaddle 1997, Polak 2003) (Figure 1). Estimators of developmental instability have been used to access the well being of populations in a variety of species and ecosystems (Graham et al. 1993, Clarke 1993, 1995a,b, Freeman et al. 1996, Lens et al. 2002) including salmonids (e.g., Leary et al. 1983, 1985a, 1993, Wilkins et al. 1995, Gharrett et al. 1999). These estimators are responsive to a wide range of biotic and physical stresses (Figure 1) including chemical stressors (Valentine \& Soule 1973, Jagoe \& Haines 1985, Lindsey 1988, Kieser 1992, Graham et al. 1993),

\footnotetext{
${ }^{1}$ Freeman, D.C., J.M. Emlen, J.H. Graham, R.L. Mara \& M. Tracy. 1996. Developmental instability as a bioindicator of ecosystem health. pp. 170-177. In: G.R. Barrow, E.D. McArthur, R. Sosebee \& R. Tausch (ed.) Proceedings: Shrubland Ecosystem Dynamics in a Changing Environment, Las Cruces, NM.
}

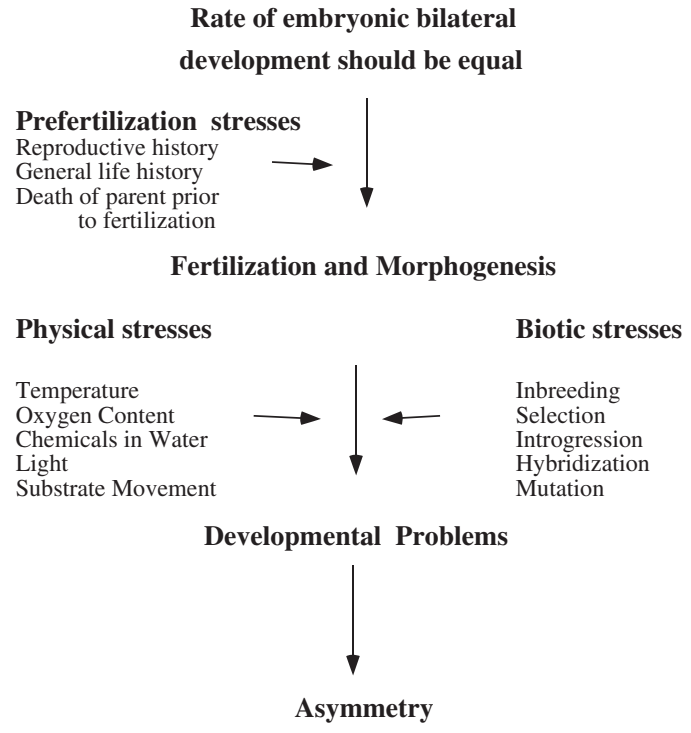

Figure 1. Conceptual model of how pre- and post-fertilization biological and physical stresses may result in meristic variation and asymmetry.

parasites (Alados et al. 1993, Polak 1994, Escos et al. 1995, Mara 1995, Perez-Tris et al. 2002), inbreeding (Leary et al. 1985c, 1987, Markow \& Martin 1993), and hybridization (Leamy 1984, Leary et al. 1985b, Gharrett \& Smoker 1991, Graham 1992, Gharrett et al. 1999, Alibert \& Auffray 2003).

Development of corresponding morphological characters (such as pectoral fins) on opposite sides of an organism are controlled by the same genes and in theory, should show perfect bilateral symmetry (Van Valen 1962). However, stresses (Figure 1) during morphogenesis can cause random changes in an organism's developmental program and result in asymmetry. Asymmetrical development, unlike changes in morphometric characters, can only be modified during early development. Once meristic characters become fixed during embryogenesis, they remain unchanged, regardless of subsequent changes in the environment or an organism's body size and shape (Waddington 1940, review in Møller \& Swaddle 1997). Instability during development is assumed to result in lower fitness due to reduced performance during natural and sexual selection (Palmer \& Strobeck 1986, Møller \& Swaddle 1997, Møller 1997). However, not all studies have found a negative relation between developmental instability and fitness (Markow \& Ricker 1992, Ueno 1994, Martin \& Hosken 2002). 
In the literature, a common estimator of developmental instability is fluctuating asymmetry (FA), the random fluctuations in meristic counts from the left and right sides of an organism. FA is believed to arise from the organism's inability to buffer development against biological or environmental disturbances (Van Valen 1962, Palmer \& Strobeck 1986, 1992). Other kinds of asymmetry, such as directional asymmetry (DA) and antisymmetry, can also occur when deviations from perfect symmetry are not random, but develop in a particular direction. The mean of the left and right deviations under fluctuating asymmetry should be zero, but with DA, the individuals are either left or right dominant. Antisymmetry is a pattern of left $(\mathrm{L})$ and right $(\mathrm{R})$ counts where the counts are directional, but not consistently so, and the pattern is bimodal. An example of antisymmetry is claw size in fiddler's crabs, where one claw is always larger than the other, but is not consistently the right or left (Neville 1976). Other examples of antisymmetry include the direction, the sail is set in wind blown jellyfish such as Vellela vellela or the direction of crossing in the beak of crossbill birds (Loxia curvirostrea) (Neville 1976).

Supplementation of wild salmon populations with hatchery stocks involves the intentional integration of hatchery and wild populations. Supplementation should result in the introgression of genes from hatchery fish into the naturalized (supplemented) populations once these hatchery fish return and spawn with the wild fish. The nature and magnitude of the consequences of this interbreeding will depend on two different types of effects. The first effect is one of stock origin: if the hatchery stock was derived from a different population than the one being supplemented, progeny of hatchery-wild matings might exhibit outbreeding depression due to different local adaptations of the source and supplemented populations. Outbreeding depression is the reduction in fitness caused by hybridization among genetically distinct parents and is caused by two mechanisms, the 'dilution' of locally adapted genotypes or through the loss of co-adapted gene complexes (Alibert \& Auffray 2003). The second effect arises from domestication, or genetic change due to selective differences in the hatchery and wild environments. Even a locally derived hatchery population can diverge over time from its local source population. These changes could also lead to outbreeding depression if the hatchery population was subsequently used for supplementation. If the hatchery stock is recently derived from a local population and the hatchery and wild populations are well mixed each generation, substantial divergence between the hatchery and wild populations would not be expected. However, because of the cumulative effects of domestication, the hatchery-wild system as a whole would be expected to genetically diverge over time from the original wild population, with the most likely outcome being a reduction in average fitness in the wild environment (Reisenbichler \& Rubin 1999, Lynch \& O’Hely 2001, Ford 2002).

Our hypothesis is that supplemented populations will show changes in levels of FA compared to their parent wild or hatchery populations. Soule (1967) suggested that populations in hybrid zones should show increased developmental instability due to the breakdown in genomic co-adaptation and outbreeding depression. However, the direction of this change may be difficult to predict, as developmental stability is theoretically expected to be enhanced by moderate outbreeding before decreasing in highly outbred groups (Vrijenhoek \& Lerman 1982). Actual studies have given conflicting results. As an example, Felley (1980) investigated a zone of secondary species contact in blue gill sunfish and found no evidence of lowered developmental homeostasis, but Graham and Felley (1985) found that more recently introgressed populations of centrarchids had higher FA levels than either of the parental populations.

In a survey of 47 studies of developmental instability in hybrids among genus, species, subspecies, and populations, Alibert \& Auffray (2003) found instability decreased in 11 studies, increased in 25, and did not change in 11. One of these studies, Freeman et al. (1995) is recorded twice as they found two traits with increased instability and two with decreased instability. Seven of these studies were of crosses among salmonids. In these studies, three reported increased levels of FA (Leary et al. 1985b, Gharrett \& Smoker 1991, Wilkins et al. 1995), two showed decreased levels of FA (Ferguson 1986, 1988), and one found no change in FA (Gharrett et al. 1999). In studies of hybridization below the species level, five studies found increased levels of instability, five had no change, and four showed decreased instability. These conflicting results are not surprising, as we know little about the genetic and/or environmental forces that mediate development in populations.

Differences in the genetic and/or environmental forces among groups of hatchery, wild, and natural chinook are at least equally murky. Compared to streams, hatcheries provide a protected rearing habitat for salmonids, but the two environments may be 
dramatically different in many other ways, including differences in mate selection criteria, pre-spawning mortality, egg densities, water temperature, oxygen content, and $\mathrm{pH}$. Because hatcheries usually rear salmon eggs in far denser conditions than in the wild, prophylactic chemical baths are often used to prevent or treat infections, diseases, and other problems (Piper et al. 1982). Although these chemicals increase embryo and juvenile survival, they may result in increased levels of stress and developmental instability in hatchery fish (Smith \& Piper 1972, Piper et al. 1982).

In this study, we attempted to estimate developmental instability in chinook salmon using two indices of FA (FA1 and FA5). We collected juvenile salmon over 3 years from streams with no hatchery planting records (wild), from streams previously supplemented with hatchery fish (natural), and from associated hatcheries. We calculated levels of FA from bilateral characters and tested to see if they might reveal changes attributable to hatchery supplementation, years of collection, or drainage of collection site. More generally, we attempted to determine whether changes in FA levels across all populations in the basin could be used as leading indicators of demographic change prior to its occurrence.

\section{Materials and methods}

\section{Study design}

Juvenile chinook salmon (Oncorhynchus tshawytscha) were collected in 1989-1991 (1988-1990 broodyears) from five drainages in the Snake River Basin in Idaho and Oregon (Figure 2, Table 1). Whenever possible, yearly samples were collected in each basin from (1) a hatchery population; (2) a hatchery supplemented, but naturally reproducing population; and (3) a wild population considered by state fishery agencies to be uninfluenced by hatchery releases (Table 1). However, samples from these different types of management scenarios were not always available each year. For example, samples from the Upper Salmon River (supplemented stream) were available only in 1989, and samples from Catherine Creek (supplemented stream) on the Grande Ronde River were available only in 1990. An isolated wild population in Marsh Creek on the Middle Fork of the Salmon River was sampled in all years to allow a comparison with basins that have been influenced by supplementation and hatchery programs. Hatchery samples were collected from two facilities that use broodstock derived from local chinook salmon populations (Sawtooth Hatchery and Imnaha facility) and two that use broodstock originally collected outside the local watershed (Looking glass and McCall hatcheries) (Table 1).

\section{Sample collections}

Juvenile chinook salmon from streams managed as wild or natural (supplemented) were collected in August and September by seine and electroshocker along stream reaches of $\sim 0.5-1 \mathrm{~km}$. Efforts were made in supplemented streams to avoid sampling planted fish that were not the result of natural spawning. Juvenile hatchery fish were sampled from August to February of each year (primarily later in the season) with dip nets from raceways containing progeny of the targeted population. All fish were killed by an overdose of MS-222 and placed on dry ice for transport to and storage in the laboratory at $-80^{\circ} \mathrm{C}$. Detailed collection of information is provided for 1989 and 1990 in Waples et al. (1993). All fish were 1-year-old juveniles, so fish collected in 1989 were 1988 broodstock.

\section{Character counts}

Eight bilateral meristic characters previously shown to exhibit asymmetry in salmonid fishes (Landrum 1966, Leary et al. 1983, 1984) were counted under a binocular dissecting microscope (Figure 3): pectoral fin rays (P1), pelvic fin rays (P2), mandibular pores (MP), lower first branchial arch gill rakers (LGR1), upper first branchial arch gill rakers (UGR1), lower second branchial arch gill rakers (LGR2), upper second branchial arch gill rakers (UGR2), and branchiostegal rays (BR). Counts were made on $\sim 40$ randomly selected chinook salmon from each site in each year. Data were pooled from males and females because no differences between sexes in the variance and means of these characters have been reported in salmonids (Landrum 1966, Leary et al. 1983 , 1984). BR counts were not used in the analysis of FA indices as they were only collected in 1989 and 1991 and the character displayed strong directionality that has been associated with an anatomical advantage to the organism (Landrum 1966, Lagler et al. 1977).

\section{Measurement error}

The estimation of individual FA is subject to large measurement or counting errors and several authors have discussed methods to increase repeatability $(\mathrm{R})$ in FA 


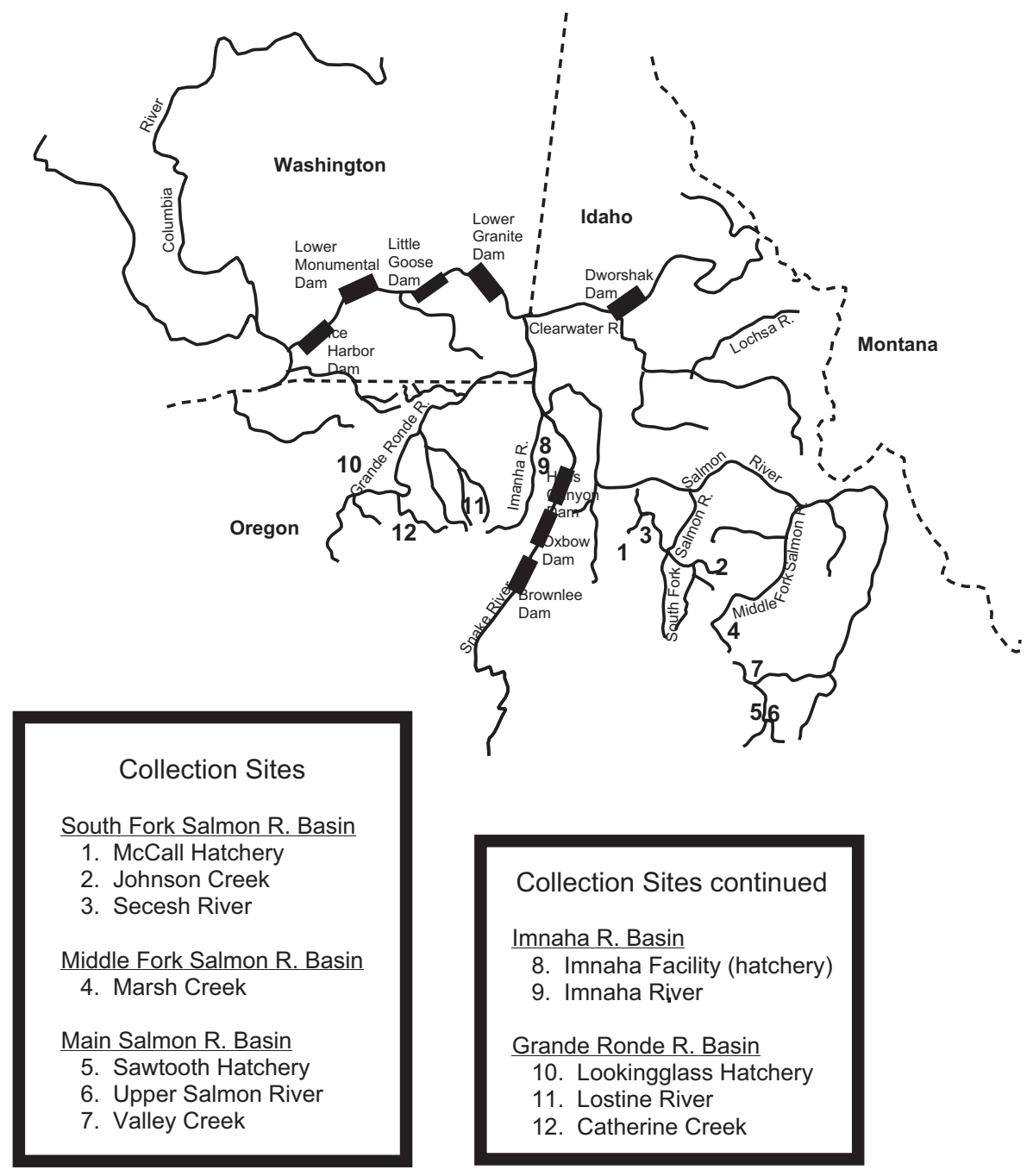

Figure 2. Map of lower Snake River Basin with collection sites numbered.

samples (Palmer \& Strobeck 1986, 1992, Whitlock \& Fowler 1997, Palmer 1994, Van Dongen 1999). In our study, each character was counted three times and repeatability of character counts was checked through periodic tests of within and between-counter variability on counts from the same fish. Differences among repeated character counts by the same technicians were near zero. However, when we totaled $\mathrm{R}$ and $\mathrm{L}$ counts from different technicians of selected characters on the same fish, differences among counters initially averaged almost $10 \%$. This was because some technicians counted more elements in a character than others did. However, there were no significant differences in FA values between technicians; the differences were in the total number of character elements counted. As an example, some counters included gill rakers that were visible under the skin, but had not yet erupted to the surface of the gill arch. Others did not. After further training and continual communication among counters, these differences were reduced to zero.

We tested for the significance of non-DA relative to counting error by using a two-way analysis of variance (ANOVA) (sides $x$ individuals). We found no statistical differences in counts of the same samples between the two counters. However, as pointed out by Palmer \& Strobeck (1986) and Palmer (1994), an ANOVA may miss actual differences when sides differ by only one or two (as with these bilateral character counts). Therefore, a low level of undetected scoring error may exist. 
Table 1. Collection sites for chinook salmon in 1989-1991 in Snake River basin (see Figure 1 for locations on map).

\begin{tabular}{|c|c|c|c|c|c|}
\hline \multirow[t]{2}{*}{ Drainage } & \multirow[t]{2}{*}{ Collection site } & \multirow[t]{2}{*}{ Run-time } & \multirow[t]{2}{*}{ Type } & \multicolumn{2}{|c|}{ Hatchery broodstock Years } \\
\hline & & & & Origin & Sampled \\
\hline \multicolumn{2}{|c|}{ South Fork Salmon River } & Summer & & & \\
\hline & McCall Hatchery & & Hatchery & $\begin{array}{l}\text { Collected at Little } \\
\text { Goose Dam }\end{array}$ & All years \\
\hline & Johnson Creek & & Natural & & All years \\
\hline & Secesh River & & Wild & & All years \\
\hline \multicolumn{2}{|c|}{ Middle Fork Salmon River } & Spring & & & \\
\hline & Marsh Creek & & Wild & & All years \\
\hline \multicolumn{2}{|c|}{ Main Fork Salmon River } & Spring & & & \\
\hline & Sawtooth Hatchery & & Hatchery & In basin & All years \\
\hline & Upper Salmon River & & Natural & & 1989 \\
\hline & Valley Creek & & Wild & & All years \\
\hline \multirow[t]{3}{*}{ Imnaha $R i$} & & Summer & & & \\
\hline & Imnaha Facility & & Hatchery & In basin & All years \\
\hline & Imnaha River & & Natural & & $1989 / 1990$ \\
\hline \multicolumn{2}{|c|}{ Grande Ronde River } & Spring & & & \\
\hline & Looking glass Hatchery & & Hatchery & $\begin{array}{l}\text { Stock - Rapid } \\
\text { R. Hatchery, Idaho }\end{array}$ & All years \\
\hline & Lostine River & & Wild & & All years \\
\hline & Minam River & & Wild & & 1990 \\
\hline & Catherine Creek & & Natural & & 1990 \\
\hline
\end{tabular}

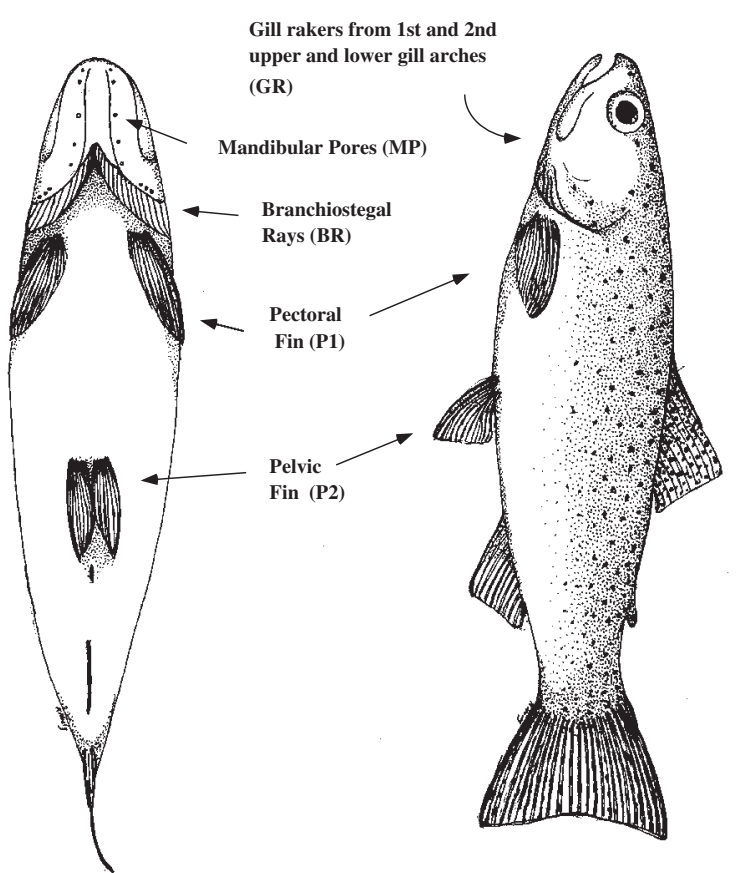

Figure 3. Bilateral characters that were counted on each fish for the study (abbreviations in parentheses).
To increase reliability of counts within a collection site, counts that differed by more than two from the mean count for that site were recounted by an additional counter. In no case did the second counter find different counts than the first. To determine if counting errors were related to fish size (bigger fish being easier to count than smaller fish), a sub-sample from the same collection site of fish greater and smaller than $80 \mathrm{~mm}$ were counted by two technicians and differences in R-L counts analyzed. Of five characters (P1, P2, MP, LGR1, and UGR1) enumerated in 20 fish (10 small, 10 large), only two fish showed any differences among counts between technicians and this only in MP. Although, more characters were omitted as uncountable in small than large fish ( 3 out of 10 smaller fish had one or more uncountable characters compared to zero in the larger fish), there were significant differences $(p>0.05)$ in FA1 or FA5 between large and small fish.

\section{Data analysis}

Correlation matrices (Sokal \& Rohlf 1981) were used to test for independence among counts of meristic characters and to determine whether a simple additive 
approach for combining data was valid for this study. Presence of antisymmetry or DA in data from individual characters was tested using a factorial ANOVA procedure (Palmer 1994) and corrected with sequential Bonferroni inequality tests for multiple samples. The normality of the meristic data was evaluated for skewness and kurtosis. High values of these results would suggest that characters might not exhibit the pattern of random bilateral variation expected during development (Palmer \& Strobeck 1992, Palmer 1994).

Statistical analyses followed the procedure of Palmer \& Strobeck (1986) and Palmer (1994) for small samples where there are not large differences in counts between characters. An asymmetry count $\left(\mathrm{A}_{\mathrm{ij}}\right)$ was obtained from each fish and character when the count taken from the left side $\left(\mathrm{L}_{\mathrm{ij}}\right)$ was subtracted from the corresponding count on the right side $\left(\mathrm{R}_{\mathrm{ij}}\right)$ to obtain the signed difference:

$$
A_{i j}=\left(R_{i j}-L_{i j}\right)
$$

where $\mathrm{i}=$ individual fish and $\mathrm{j}=$ individual character counted.

DA for a particular character was the mean of $A_{i}$.

$$
\mathrm{DA}_{\mathrm{j}}=\text { Mean } \mathrm{A}_{\mathrm{ij}}
$$

We evaluated several indices of FA and choose two (FA1 and FA5) that met the characteristics of our dataset, as recommended in Palmer (1994). FA1 is the absolute or unsigned value of DA (Palmer \& Strobeck 1986, 1992):

$$
F A 1_{j}=\text { Mean }\left|A_{i j}\right|
$$

FA1 is easy to compute and is intuitively easy to understand, because it is simply the unbiased estimator of the sample standard deviation, and it is relatively insensitive to outliers. This FA estimator will be biased if either DA or antisymmetry is strongly present, and its statistical power is less than some other estimators. It is also sensitive to size of the difference between $\mathrm{R}$ and L counts.

FA5 is a population estimator of FA for a particular character and is the mean squared $\mathrm{A}_{\mathrm{i}}$ divided by number of fish counted $\left(\mathrm{N}_{\mathrm{j}}\right)$ (Palmer \& Strobeck 1986):

$$
\mathrm{FA}_{\mathrm{j}}=\frac{\sum\left(\mathrm{A}_{\mathrm{i}}\right)^{2}}{\mathrm{~N}_{\mathrm{j}}}
$$

FA5 is an estimator of the between-sides variance of the data and allows an added degree of freedom over the standard variance as the mean is assumed to be non-zero. Thus, this index has added statistical power, particularly for samples $<40$, but it is also biased by either DA or antisymmetry and it is more sensitive to outliers than FA1. It is also sensitive to the size dependence of $|\mathrm{R}-\mathrm{L}|$.

Statistical procedures (regression and ANOVA) were used to determine the effect of length, site of collection, drainage of collection site, and type of fish (wild, hatchery, or natural) on the meristic variables. When multiple significance tests were conducted (e.g., number of statistically significant differences among FA values at the different collection sites), we used a sequential Bonferroni inequality test to reduce the occurrence of false positive results to $5 \%$ or less (Rice 1989, Palmer 1994, Anderson \& Finn 1996).

\section{Results}

\section{Independence of character counts}

A correlation matrix of $\mathrm{A}_{\mathrm{i}}$ for the seven characters from 1,123 chinook (241 fish had one or more characters missing) showed only two characters, P1 and UGR2, to be significantly correlated ( $\mathrm{p}=0.046$ ) with a correlation of 0.059 (Table 2), after adjusting for multiple tests.

\section{Length and character counts or measurement error}

Mean length of hatchery fish $(104.6 \mathrm{~mm} \pm 0.8 \mathrm{SE})$ was significantly greater $(\mathrm{p}<0.001)$ greater than either wild $(68.61 \pm 0.4 \mathrm{~mm})$ or natural fish $(65.2 \pm 0.5 \mathrm{~mm})$. Wild fish were also longer than fish from supplemented sites $(\mathrm{p}=0.026)$, although the average length was

Table 2. Correlation matrix of asymmetry indices $\left(\mathrm{A}_{\mathrm{i}}\right)$ for all values, excluding $\mathrm{BR}$, from chinook salmon in all years from all sites.

\begin{tabular}{llllrlrr}
\hline Characters & P1 & P2 & MP & LGR1 & UGR1 & LGR2 & UGR2 \\
\hline P1 & \multirow{2}{*}{1.00} & 0.03 & -0.03 & 0.00 & 0.01 & -0.02 & 0.06 \\
P2 & & 1.00 & -0.04 & -0.04 & 0.02 & 0.01 & -0.02 \\
MP & & & 1.00 & 0.03 & 0.02 & 0.03 & -0.01 \\
LGR1 & & & & 1.00 & 0.04 & 0.00 & 0.00 \\
UGR1 & & & & & 1.00 & 0.00 & 0.01 \\
LGR2 & & & & & & 1.00 & 0.03 \\
UGR2 & & & & & & & 1.00
\end{tabular}

There were 1,123 observations used in the matrix and 231 cases omitted due to missing values. Asterisk (*) indicates value is statistically significant $(\mathrm{p}<0.05)$. 
only $2.2 \mathrm{~mm}$ greater. There were no significant differences in length between fish collected in different years.

Since it is easier to count characters in larger fish than smaller fish, there was a significant positive correlation between fish length and total number of elements per character counted $\left(\mathrm{R}=0.447, \mathrm{R}^{2}=0.200\right.$, and $\mathrm{p}<0.001$ ) for all characters except LG2. Even when counts were restricted to fish less than $80 \mathrm{~mm}$ in length (61 hatchery, 244 natural, and 447 wild fish), length was still significantly correlated to character counts ( $\mathrm{p}=0.0004)$.

However, using regression analysis, we found no significant correlation of length with $\mathrm{A}_{\mathrm{ij}}(\mathrm{p}=0.2550$, $\left.\mathrm{R}^{2}=0.001\right)$, FA1 $\left(\mathrm{p}=0.3218, \mathrm{R}^{2}=0.001\right)$, or FA5 $\left(\mathrm{p}=0.5832, \mathrm{R}^{2}=0.010\right)$. We concluded that although more characters could be seen and counted in larger fish, the increases were equal on both sides of the fish.

\section{Directional asymmetry pattern of counts for individual bilateral characters}

Following Palmer (1994), we tested our data to determine whether individual characters showed consistent directionality in counts of the L and R sides. Student's t-tests comparing raw $\mathrm{L}$ and $\mathrm{R}$ character counts indicated only one character (1LGR) had statistically different $(\mathrm{p}=0.02)$ bilateral counts. The mean DA values for all characters in the study were slightly negative (Table 3). However, after sequential Bonferroni correction for multiple tests, factorial ANOVA tests on counts from left and right sides of all characters (Palmer 1994) indicated means were not significantly different from zero $(\mathrm{p}<0.01)$.

\section{Normality of data - kurtosis and skewness}

Kurtosis and skewness were calculated for each bilateral character following Palmer (1994) (Table 3). Skewness of counts from all characters is low with no statistical differences among characters $(p=0.08)$. The kurtosis index for all characters (especially P1, P2) was positive, indicating a leptokurtotic distribution for the data (Table 3). These results are within a range similar to that calculated from asymmetry indices of the same characters in other studies (e.g., Leary et al. 1984, 1985). Kurtosis of the mean values for all characters across fish was less than one (0.97), further indicating the data were normally distributed.

Asymmetry in years, drainages, sites, and type of management (wild, natural, or hatchery)

The data were analyzed to determine if differences in asymmetry could be partitioned by collection, year, site, drainage, or fisheries management type (wild, hatchery, or natural). There were 13 collection sites: 11 in 1989, 12 in 1990, and 10 in 1991. Nine sites were replicated in all 3 years, so we grouped all sites by year for analysis. Summary of data for collections sites, including mean DA, FA1, and FA5, is presented in Table 4.

There were significant differences in FA among years of collection. ANOVA of both FA1 and FA5 indices showed significant $(\mathrm{p}=0.001)$ declines from 1989 to 1991 (Figure 4). FA5 indices were significantly greater in 1989 than in both 1990 (mean $0.31 \pm 0.013$, $\mathrm{p}=0.04$ ) and 1991 (mean $0.27 \pm 0.013, \mathrm{p}=0.003$ ), but not between 1990 and $1991 \quad(\mathrm{p}=0.1525)$. Indices of FA1 from fish collected in 1989 (mean $=0.31 \pm 0.01)$ were significantly greater than

Table 3. Character summaries of asymmetry indices for DA and FA $\pm S E . N_{t}$ is the number of fish counted per character.

\begin{tabular}{|c|c|c|c|c|c|c|c|c|c|}
\hline \multirow[t]{2}{*}{ Character } & \multicolumn{2}{|l|}{ DA } & \multirow[t]{2}{*}{$\mathrm{N}_{\mathrm{t}}$} & \multirow[t]{2}{*}{ Skewness } & \multirow[t]{2}{*}{ Kurtosis } & \multicolumn{2}{|l|}{ FA1 } & \multicolumn{2}{|l|}{ FA5 } \\
\hline & Mean & SE & & & & Mean & SE & Mean & SE \\
\hline P1 & -0.01 & 0.02 & 1235 & 0.52 & 7.78 & 0.24 & 0.01 & 0.28 & 0.04 \\
\hline P2 & -0.01 & 0.01 & 1209 & -0.55 & 11.13 & 0.13 & 0.01 & 0.14 & 0.03 \\
\hline MP & -0.03 & 0.02 & 1189 & 0.13 & 1.05 & 0.40 & 0.02 & 0.43 & 0.03 \\
\hline LGR1 & -0.02 & 0.02 & 1255 & -0.09 & 1.81 & 0.35 & 0.02 & 0.38 & 0.02 \\
\hline UGR1 & -0.01 & 0.02 & 1258 & -0.10 & 1.66 & 0.39 & 0.02 & 0.43 & 0.03 \\
\hline LGR2 & -0.03 & 0.01 & 1248 & -0.33 & 2.21 & 0.24 & 0.01 & 0.25 & 0.02 \\
\hline UGR2 & -0.01 & 0.02 & 1245 & -0.07 & 2.62 & 0.26 & 0.01 & 0.28 & 0.02 \\
\hline Mean & -0.02 & 0.01 & 1284 & 0.01 & 0.97 & 0.29 & 0.01 & 0.05 & 0.00 \\
\hline BR & -1.14 & 0.04 & 719 & 0.04 & 7.73 & 1.23 & 0.03 & 1.32 & 0.24 \\
\hline
\end{tabular}

Mean skewness \pm 0.07 . Mean kurtosis \pm 4.04 . 
Table 4. Values of mean DA, FA1, and FA5 \pm SE for collection sites pooled by years.

\begin{tabular}{lllcrll}
\hline Collection site & Type & $\begin{array}{l}\text { Years } \\
\text { sampled }\end{array}$ & $\begin{array}{l}\text { No. of fish } \\
\text { counted }\end{array}$ & DA \pm SE & FA1 \pm SE & FA5 \pm SE \\
\hline Catherine Creek & $\mathrm{N}$ & 1 & 40 & $-0.04 \pm 0.04$ & $0.24 \pm 0.02$ & $0.26 \pm 0.02$ \\
Imnaha Hatchery & $\mathrm{H}$ & 3 & 119 & $-0.03 \pm 0.02$ & $0.29 \pm 0.02$ & $0.31 \pm 0.02$ \\
Imnaha River & $\mathrm{N}$ & 2 & 80 & $0.02 \pm 0.03$ & $0.28 \pm 0.02$ & $0.31 \pm 0.01$ \\
Johnson Creek & $\mathrm{N}$ & 3 & 120 & $-0.02 \pm 0.02$ & $0.28 \pm 0.02$ & $0.33 \pm 0.05$ \\
Looking glass Hatchery & $\mathrm{H}$ & 3 & 120 & $0.01 \pm 0.02$ & $0.28 \pm 0.02$ & $0.28 \pm 0.01$ \\
Lostine River & $\mathrm{W}$ & 3 & 120 & $0.02 \pm 0.02$ & $0.29 \pm 0.02$ & $0.29 \pm 0.01$ \\
Marsh Creek & $\mathrm{W}$ & 3 & 126 & $-0.02 \pm 0.02$ & $0.30 \pm 0.02$ & $0.34 \pm 0.08$ \\
McCall Hatchery & $\mathrm{H}$ & 3 & 117 & $-0.09 \pm 0.02$ & $0.32 \pm 0.02$ & $0.35 \pm 0.04$ \\
Minam River & $\mathrm{W}$ & 1 & 40 & $0.01 \pm 0.03$ & $0.27 \pm 0.03$ & $0.33 \pm 0.04$ \\
Sawtooth Hatchery & $\mathrm{H}$ & 3 & 121 & $-0.04 \pm 0.02$ & $0.32 \pm 0.02$ & $0.38 \pm 0.07$ \\
Secesh River & $\mathrm{W}$ & 3 & 121 & $0.01 \pm 0.02$ & $0.27 \pm 0.02$ & $0.28 \pm 0.04$ \\
Upper Salmon River & $\mathrm{N}$ & 1 & 40 & $0.02 \pm 0.03$ & $0.27 \pm 0.02$ & $0.29 \pm 0.03$ \\
Valley Creek & $\mathrm{W}$ & 3 & 120 & $-0.01 \pm 0.02$ & $0.28 \pm 0.02$ & $0.29 \pm 0.03$ \\
\hline Becau data for & & & &
\end{tabular}

Because data for BR were not collected in 1990, data from character was not included in calculations of DA or FA. Type is management type ( $\mathrm{N}=$ natural, $\mathrm{W}=$ wild, and $\mathrm{H}=$ hatchery).

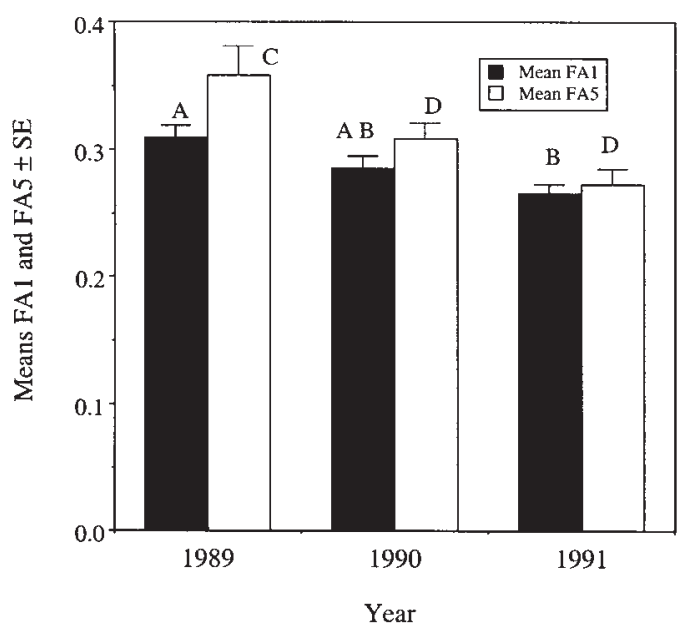

Figure 4. Fluctuating asymmetry (FA1 and FA5) indices from fish collected in different years (i.e., different broodyears). Both indices had statistically significant differences among years $(\mathrm{p}=0.01$ for FA1 and 0.009 for FA 5). FA1 indices of fish collected in 1989 were significantly greater (indicated with A) than fish collected $1991(\mathrm{p}<0.001)(B)$, but not $1990(\mathrm{p}>0.05)$ (AB). FA5 indices in 1989 were significantly greater (indicated with C) than fish collected both in $1990(\mathrm{p}<0.05)(\mathrm{D})$ and 1991 $(\mathrm{p}<0.001)(\mathrm{D})$. Fish collected in 1990 were not significantly different from fish collected in $1991(\mathrm{p}>0.10)$.

1991 (mean $0.37 \pm 0.01, \mathrm{p}=0.0012$ ), but indices in 1990 (mean $0.29 \pm 0.01$ ) were not different from 1989 $(\mathrm{p}=0.068)$ or $1991(\mathrm{p}=0.1232)$.

We found no significant differences in either FA1 $(\mathrm{p}=0.48)$ or FA5 $(\mathrm{p}=0.89)$ among collection sites.
Catherine Creek (only sampled in 1990) had the lowest mean FA values for both FA1 $(0.24 \pm 0.02)$ and FA5 $(0.26 \pm 0.02)$. Sawtooth Hatchery demonstrated the highest mean FA5 mean value $(0.38 \pm 0.07)$. McCall Hatchery had the highest mean FA1 value $(0.32 \pm 0.02)$ and the second highest mean FA5 $(0.35 \pm 0.04)$ value (Table 4). There were no significant differences in FA among management types (FA1 $\mathrm{p}=0.18$ and FA5 $\mathrm{p}=0.65)$.

\section{Counter measurement error}

Four scientists counted all chinook salmon characters in the study. In general, two counters had primary responsibilities for 1989 and 1990 and a two had primary responsibility for 1991 . There were significant differences in FA among years, and there is the potential that these yearly differences represent differences in counts among technicians rather than differences among fish. However, there was overlap among years for all technicians and there are no significant differences among technicians in overall character counts $(\mathrm{p}=0.55)$, in DA $(\mathrm{p}=0.56)$, or in FA1 $(\mathrm{p}=0.33)$

\section{Discussion}

Lack of significant differences among hatchery, wild, and natural fish

The purpose of the study was to evaluate the use of FA to detect changes in developmental instability in 
juvenile fish from streams where hatchery-reared fish are planted onto wild populations. We analyzed two FA indices (FA1 and FA5) and found no statistical differences among hatchery fish, naturally spawning fish in streams with previous hatchery plants (natural), or naturally spawning fish from streams without known hatchery supplementation (wild). Nor did we find significant differences (after corrections for multiple tests) among collection sites or drainage basins (over all collection years). However, we did detect significant differences in overall and character means of both FA1 and FA5 among fish collected in different years, regardless of management type, collection site, or drainage (Figure 4).

Several hypotheses can be proposed for the lack of difference in FA indices among hatchery, wild, and natural populations.

(1) Developmental instability was sufficiently low across the region buffering developmental problems during embryogenesis regardless of wild, hatchery, or natural origin.

(2) Hatchery fish planted into streams that contained wild fish did not survive, or if they did survive, their reproductive success with wild fish was negligible.

(3) Hatchery fish survived and produced hybrid offspring that did not experience increased developmental instability.

(4) Large region-wide environmental perturbations caused increased stress and developmental instability in most Snake River chinook populations and obscured any differences detected by FA among management types.

All these hypotheses may have occurred and may be contributors to the lack of significant differences in mean FA among hatchery, wild, and natural fish. However, the first hypothesis, that instability was low across all populations, has little support. Salmon populations in the region have experienced repeated population declines and environmental alterations (reviewed in Magnuson 1996) at a level that, in other species, has resulted in detectable changes in developmental instability (Freeman et al. 1995, Zakharov 2003). The second hypothesis, that planted hatchery fish had low rates of survival and/or poor reproductive success, has general support in the literature (e.g., Chilcote et al. 1989, Leider 1990). A genetic model has been proposed (Emlen 1991) that shows interbreeding between genetically distinct hatchery and wild populations may substantially reduce productivity for more than
10 generations after interbreeding. However, although a number of studies on hatchery-wild reproductive success among chinook salmon are in progress, none have yet been published.

The third hypothesis, that hybrid offspring did not experience increased developmental instability, or that changes were insufficient to be detected in our analysis, is possible. The relationships of genomic co-adaptation, outbreeding depression, and developmental instability during hybridization are complex, confusing, and often unpredictable (Alibert \& Auffray 2003). Detectable changes would partially depend on the differences among hatchery and wild stocks, and the differential mortality or reproductive success that hatchery and wild fish might experience during their life history. However, differences in FA from other studies on salmonid hybrid crosses, using a variety of indices (e.g., Leary et al. 1985b, Ferguson 1986, 1988, Gharrett \& Smoker 1991, Wilkins et al. 1995, Gharrett et al. 1999) would suggest the technique is adequately sensitive to detect any changes in developmental instability that did occur among these hatchery-wild crosses.

The fourth hypothesis, that large scale environmental and other changes overwhelmed differences related due to wild-hatchery interactions also seems plausible. Throughout the Pacific Northwest during the late 1980s and early 1990s, salmon experienced freshwater and ocean conditions which resulted in changes in population structure and significant declines in abundance in many salmon stocks (Magnuson 1996). An example of other changes that may have altered population structure include the widespread straying of supplemented chinook salmon which have been documented to have occurred in the Grande Ronde during these years $\left(\right.$ Crateau $\left.^{2}\right)$.

The significant differences detected in FA among fish collected in 1989-1991 (broodyears 1988-1990, respectively) occur across management types, collection sites, and river drainages, suggesting a basin-wide cause. It has been shown in previous studies (Allenbach et al. 1999) that FA is increased in organisms that develop in a stressful and/or marginal environment. The mid-1980s to early 1990s were drought years across the Snake River Basin. Precipitation was lowest in 1988,

\footnotetext{
${ }^{2}$ Crateau, E. 1997. Straying of hatchery origin spring/summerrun chinook salmon in the Grande Ronde Basin. In: W.S. Grant (ed.) Genetic Effects of Straying of Non-Native Hatchery Fish into Natural Populations. Proceedings of the Workshop, June 1-2, 1995, Seattle, WA.
} 
increased slightly in 1989, but declined again from 1990-1993. ${ }^{3}$ This drought may have added stress both to spawners prior to fertilization and to embryos during incubation in 1988 through increased water temperatures, low spawner concentrations, increased predation, and other factors. The slightly improved conditions in 1989 and 1990 may be reflected in the higher FA values from some sites in 1990 and 1991.

It is interesting that the highest FA values from 1989 were from Marsh Creek in the Salmon River. This creek is located in the Middle Fork of the Salmon River, a drainage within the Salmon River that does not have any hatcheries or hatchery-enhanced streams (Figure 2). However, the next highest FA values were from fish reared at two hatcheries (McCall and Sawtooth), also from the greater Salmon River Basin. These three sites also had the highest mean FA values in 1990 (along with wild fish from the Secesh River, a tributary of the South Fork Salmon River). However, in 1991, Marsh Creek and Secesh River had the lowest FA values (i.e., developmental instability), while the two Salmon River hatcheries had FA values in the middle of the FA distribution for that year. As noted in Palmer (1994), outliers or miscounts in a dataset can exaggerate $\mathrm{FA}$ indices, but the values for these sites appear to be true counts of bilateral asymmetry and not the result of injury or counting error.

\section{Did FA vary with size of fish?}

We did find significant differences in fork length between hatchery and naturally spawning fish, which might have resulted in a bias in our results. The mean length of hatchery fish was nearly $65 \%$ larger than the mean length of either wild or natural fish. The significant differences in length between wild and natural fish (even though small) are more surprising as both types of fish are from naturally spawning parents, and would be expected to have experienced natural rearing environments. However, streams are usually supplemented with hatchery fish because the natural fish populations have declined. The causes of this decline may still be impacting the supplemented populations and could result in a reduction in fish size.

We also found that more characters could be counted in larger fish than smaller fish, so the mean of characters counted in hatchery fish was significantly larger

\footnotetext{
${ }^{3}$ Western Regional Climate Center. 2002. 2215 Raggio Parkway, Reno, NV 89512.
}

$(\mathrm{p}>0.05)$ for most traits than in wild or natural fish. There were no statistical differences among naturally spawning fish ( $p>0.05)$. Palmer (1994) has pointed out that apparent asymmetry may be influenced by trait size and can cause spurious results in studies of development stability. However, we did not find significant differences $(\mathrm{p}<0.05)$ in DA, FA1, or FA5 among fish of different sizes in our study, even though larger fish had more countable characters than smaller fish. Therefore, in our study, the question, 'Does FA vary with size' can be answered, 'No.'

Several authors have suggested that size of organisms within a population may bias FA analysis because the size may reflect differences in general 'condition' of the organism (reviewed in Møller 1997). This concept is rooted in the view of developmental instability as an easily measured surrogate for fitness, even though it has been shown that developmental processes are not linear but rather complex, dynamic, and non-linear (Graham et al. 1993, 1998, Møller 1997). In this study, the mean length of hatchery fish was significantly larger, by over $65 \%$, than either of the naturally spawned groups. However, it is unlikely the size differential represented increased condition or fitness, but more likely reflected collection timing and rearing conditions. Wild and natural fish were all collected during August and early September, while hatchery fish were usually collected November through January, giving hatchery fish 3-5 months longer to grow. In addition, hatchery fish are fed to satiation in a protected environment with stable temperatures and no predators and would be expected to be larger than stream fish at the same age. Conversely, wild or natural fish that are unfit, sick, or in poor condition would probably be smaller than fish that are fit, healthy, and robust. However, these small fish would also be more likely to die or be eaten than bigger fish and so not be included in this study. More study would be needed to determine if size differences among fish from different management types correlates to increases in their condition or fitness.

\section{Why use FA and not DA?}

Fluctuating Asymmetry measures developmental errors during morphogenesis (i.e., the number of times the organism is unable to develop equally numbered bilateral elements), whereas DA and antisymmetry are believed to measure patterns of morphological development, which may have an adaptive purpose and an inherited (genetic) component (e.g., human heart and 
fiddler crab claws) (Graham et al. 1998). However, there has been an extensive debate in the literature of the values of using deviations from antisymmetry and DA as measures of developmental instability (Palmer \& Strobeck 1992, Graham et al. 1993, 1998, McKenzie \& O’Farrell 1993).

Studies have shown that if FA occurs in an organism, it is possible to induce an evolutionary change to DA in response to intense directional selection (e.g., Mather 1953, McKenzie \& Clarke 1988, Leary \& Allendorf 1989, Graham et al. 1993). These findings would support claims that DA, antisymmetry, and FA are 'dynamically interrelated' (Graham et al. 1993b), can be co-produced by stressed environments, and all represent a form of developmental instability. Further, Graham et al. (1998) have presented a method to estimate developmental instability from DA data using residual variance from either a major axis regression or a general structural model.

In our study, only two individual characters displayed statistically significant directionality (i.e., more counts consistently to one side than the other). The first, BR, showed significantly more counts on the left than the right ( $\mathrm{p}<0.0001$ ), but was excluded from the study because samples were not counted in 1990 . In addition, BR has been associated with an anatomical advantage to the organism (Landrum 1966, Lagler et al. 1977). Only one other character in the study had a statistically significant directionality $(\mathrm{p}=0.02)$ across all samples and that was LGR1 (mean number of rakers on right was $8.66 \pm 0.91 \mathrm{SE}$, and on left $8.65 \pm 0.90$ $\mathrm{SE})$. The reason for this was unclear. However, certain groupings of collection sites also revealed DA, especially among management groups. When sub-groups of larger normally distributed asymmetry datasets reveal directionality, this deviation from perfect symmetry is less likely to be adaptive or inherited through natural selection. Further, the DA displayed by BR counts also demonstrated patterns related to different treatment groups, and these differences may indicate an embryogenic environmental insult. Graham et al. (1998, 2003) demonstrate that FA, DA, and antisymmetry are dynamically interrelated and that all three components of asymmetry must be calculated to properly estimate developmental instability. These relationships will be further investigated in future work.

\section{Conclusions}

Were the apparent high levels of population instability in 1989 and 1990 an early warning of decreased fish abundance? This is difficult to determine, as during this time, chinook salmon populations were taking a precipitous decline throughout all management groups and drainages in the Snake River Basin. In addition, during the years of this study, the region was experiencing one of the most severe droughts of the century, during which water temperatures in the region were high and flow diminished (Western Regional Climate Center ${ }^{3}$ ). Although precipitation increased beginning in 1989, the drought persisted until the mid-1990s (Western Regional Climate Center $^{3}$ ).

Analysis of FA indices was envisioned as a possible indicator of future population instability prior to actual declines in abundance. As this is a relatively non-invasive technique (only 40 lethal samples of juvenile fish from a population are required), and does not require extensive technology (binocular microscope and calipers are sufficient), a region-wide meristic database could be developed to monitor changes in FA among index populations. Changes in FA levels might alert managers that problems at the population level were occurring and this would allow preventative steps to be taken prior to demographic declines. Although we detected changes in FA among different years, the use of FA by itself did not seem to provide sufficient information to be useful in predicting future population declines. In future studies, we will include estimates of deviations from DA and antisymmetry following Graham et al. (1998), who proposed that using all these indices are crucial to properly evaluating the significance of developmental instability.

\section{Acknowledgements}

By far the most difficult task in this type of study is the consistent and accurate counting of meristic characters and the authors wish to extend a special thanks to Stacy Jones, Kathleen Neely, Amy Cook, Tami Peperell, and Ruth Levine for this challenging task. Selection of study sites and stock histories was carried out with assistance from Richard Carmichael, Oregon Department of Fish and Wildlife (ODFW), and Steve Yundt, Idaho Department of Fish and Game (IDFG). Assistance with field collections was provided by numerous field and hatchery biologists from ODFW and IDFG, along with Steve Achord, Paul Moran, and others on the National Marine Fisheries Service (NMFS) collection crews. Steve Smith and Ben Alexander of NMFS provided statistical consulting. Funding was partially provided by the Division of Fish and Wildlife, Bonneville Power Administration (Project No. 89-096). 


\section{References}

Alados, C.L., J. Escos \& J.M. Emlen. 1993. Developmental instability as an indicator of environmental-stress in the Pacific hake (Merluccius productus). Fish. Bull. 91: 587-593.

Alibert, P. \& J. Auffray. 2003. Genomic coadaptation, outbreeding depression, and developmental instability. pp. 116-134 In: M. Polak (ed.) Developmental Instability Causes and Consequences, Oxford University Press, New York.

Allenbach, D.M., K.B. Sullivan \& M.J. Lydy. 1999. Higher fluctuating asymmetry as a measure of susceptibility to pesticides in fishes. Environ. Toxicol. Chem. 18: 899-905.

Allendorf, F.W. \& N. Ryman. 1987. Genetic management of hatchery stocks. pp. 141-159. In: N. Ryman \& F. Utters (ed.) Population Genetics and Fishery Management, University of Washington Press, Seattle, WA.

Anderson, T.W. \& J.D. Finn. 1996. The New Statistical Analysis of Data. Springer-Verlag, New York.

Campton, D.E. 1995. Genetic effects of hatchery fish on wild populations of Pacific salmon and steelhead: What do we really know? pp. 337-353. In: H.L. Schramm Jr. \& R.G. Piper (ed.) Uses and Effects of Cultured Fishes in Aquatic Ecosystems. Am. Fish. Soc. Symp. 15.

Clarke, G.M. 1993. The genetic basis of developmental stability. I. Relationships between stability, heterozygosity and genomic coadaptation. Genetica 89: 15-23.

Clarke, G.M. 1995a. The genetic basis of developmental stability. II. Asymmetry of extreme phenotypes revisited. Am. Nat. 146 708-725.

Clarke, G.M. 1995b. Relationships between developmental stability and fitness: Applications for conservation biology. Conserv Biol. 9: 18-25.

Cuenco, M.L., T.H. Backman \& P.R. Mundy. 1993. The use of supplementation to aid in natural stock restoration pp. 269-293. In: J.G. Cloud \& G.H. Thorgaard (ed.) Genetic Conservation of Salmonid Fishes. Proceedings of a NATO advanced Study Institute, Plenum Press, New York.

Emlen, J.M. 1991. Heterosis and outbreeding depression: A multilocus model and an application to salmon production. Fish. Res. 12: 187-212.

Escos, J., C.L. Alados, J.M. Emlen \& S. Alderstein. 1995. Developmental instability in the Pacific hake parasitized by myxosporeans Kudoa spp. Trans. Amer. Fish. Soc. 124: 943-945.

Felley, J. 1980. Analysis of morphology and asymmetry in blue gill sunfish (Lepomis macrochirus) in the southeastern United states. Copeia 1: 1980, 18-29.

Ferguson, M. 1986. Developmental stability of rainbow trout hybrids: Genomic coadaptation or heterozygosity. Evolution 40: 323-330.

Ford, M.J. 2002. Selection in captivity during supportive breeding may reduce fitness in the wild. Conserv. Biol. 16: 815-825.

Freeman, D.C., J.H. Graham, D.W. Byrd, E.D. McArthur \& W.A. Turner. 1995. Narrow hybrid zone between two subspecies of big sagebrush, Artemisia tridentate (Asteraceae). III. Developmental instability. Amer. J. Bot. 82: 1144-1152.

Gharrett, A.J. \& W.W. Smoker. 1991. Two generations of hybrids between even- and odd-year pink salmon (Oncorhynchus gor buscha): a test for outbreeding depression? Can. J. Fish. Aq. Sci. 48: 1744-1749.
Gharrett, A.J., W.W. Smoker, R.R. Reisenbichler \& S.G. Taylor. 1999. Outbreeding depression in hybrids between odd- and even-broodyear pink salmon. Aquaculture 173: 117-129.

Graham, J.H. 1992. Genomic coadaptation and developmental stability in hybrid zones. Acta Zool. Fennica 191: 121-131.

Graham, J.H. \& J.D. Felley. 1985. Genomic coadaptation and developmental stability within introgressed populations of Enneacanthus gloriosus and E. obesus (Pisces, Centrarchidae). Evolution 391: 104-114.

Graham, J.H., D.C. Freeman \& J.M. Emlen. 1993. Antisymmetry, directional asymmetry, and dynamic morphogenesis. Genetica 89: 121-137.

Graham, J.H., J.M. Emlen, D.C. Freeman, L.J. Leamy \& J.A. Kieser. 1998. Directional asymmetry and the measurement of developmental instability. Biol. J. Linn. Soc. 64: 1-16.

Graham, J.H., J.M. Emlen \& D.C. Freeman. 2003. Nonlinear dynamics and developmental instability. pp. 35-50. In: M. Polak (ed.). Developmental Instability Causes and Consequences. Oxford University Press, New York.

Ham, K.D. \& T.N. Pearsons. 2000. Can reduced salmonid population abundance be detected in time to limit management impacts? Can. J. Fish. Aquat. Sci. 57: 17-24

Hindar, K., N. Ryman \& F. Utter. 1991. Genetic effects of cultured fish on natural fish populations. Can. J. Fish. Aquat. Sci. 48: 945-957.

Jagoe, C.H. \& T.A. Haines. 1985. Fluctuating asymmetry in fishes inhabiting acidified and unacidified lakes. Can. J. Zool. 63: 130-138.

Kieser, J.A. 1992. Fluctuating odontometric asymmetry and maternal alcohol consumption. Ann. Hum. Biol. 19: 513-520.

Lagler, K.F., J.E. Bardach, R.R. Miller \& D.R. Passion. 1977. Ichthyology, 2nd edition. John Wiley \& Sons, New York, $506 \mathrm{pp}$

Landrum, B.J. 1966. Bilateral asymmetry in paired meristic characters of Pacific salmon. Pac. Sci. 20: 193-202.

Leamy, L. 1984. Morphometric studies in inbred and hybrid house mice. V. Directional and fluctuating asymmetry. Am. Nat. 123: 579-593.

Leary, R. \& F. Allendorf. 1989. Fluctuating asymmetry as an indicator of stress: implications for conservation biology. Trends in Ecology and Evolution. 4(7): 214-217.

Leary, R.F., F.W. Allendorf \& K.L. Knudsen. 1983. Developmental stability and enzyme heterozygosity in rainbow trout. Nature 301: 71-72.

Leary, R.F., F.W. Allendorf \& K.L. Knudsen. 1984. Superior developmental stability of heterozygotes at enzyme loci in salmonid fishes. Am. Nat. 124: 540-551.

Leary, R.F., F.W. Allendorf \& K.L. Knudsen. 1985a. Inheritance of meristic variation and the developmental stability in rainbow trout. Evolution 39: 308-314.

Leary, R.F., F.W. Allendorf \& K.L. Knudsen. 1985b. Developmental instability and high meristic counts in interspecific hybrids of salmonid fishes. Evolution 39: 1318-1326.

Leary, R.F., F.W. Allendorf \& K.L. Knudsen. 1985c. Developmental instability as an indicator of reduced genetic variation in hatchery trout. Trans. Amer. Fish. Soc. 114: 230-235.

Leary, R.F., F.W. Allendorf \& K.L. Knudsen. 1987. Differences in inbreeding coefficients do not explain the association between heterozygosity at allozyme loci and developmental stability in rainbow trout. Evolution 41: 1413-1415. 
Leary, R.F., F.W. Allendorf \& K.L. Knudsen. 1993. Null alleles at two lactate dehydrogenase loci in rainbow trout are associated with decreased developmental stability. Genetica 89: 3-14.

Lens, L., S. Van Dongen \& E. Matthysen. 2002. Fluctuating asymmetry as an early warning system in the critically endangered Taita thrush. Conserv. Biol. 16: 479-487.

Lerner, I.M. 1954. Genetic Homeostasis. Wiley, New York. $134 \mathrm{pp}$.

Leung, B. \& M.R. Forbes. 1997. Modeling fluctuating asymmetry in relation to stress and fitness. OKIOS 78: 397-405.

Lindsey, C.C. 1988. Factors controlling meristic variation. pp. 197-274. In: W.S. Hoar \& D.J. Randall (ed.) Fish Physiology. Vol. XIB, Academic Press, New York

Lynch, M. \& M. O'Hely. 2001. Captive breeding and the genetic fitness of natural populations. Conserv. Genet. 2: 363-378.

Mara, R.L. 1995. Developmental Stability in Acer rubrum M.S. Thesis, Wayne State University, Detroit, Michigan. 28 pp.

Magnuson, J.J. 1996. Upstream: Salmon and Society in the Pacific Northwest. National Academy of Sciences, Washington D.C. $452 \mathrm{pp}$.

Markow, T.A. \& J.P. Ricker. 1992. Male size, developmental stability, and mating success in natural populations of three Drosophila species. Heredity 69: 122-127.

Markow, T.A. \& J. Martin. 1993. Inbreeding and developmental stability in a small human population. Ann. Hum. Biol. 20: 389-394.

Martin, O.Y. \& D.J. Hosken. 2002. Asymmetry and fitness in female yellow dung flies. Biol. J. Linn. Soc. Lond. 76: 557-563.

Mather, K. 1953. Genetical control of stability in development. Heredity 7: 297-336.

McClure, M.M., E.E Holmes, B.L. Sanderson \& C.E. Jordan. 2003. A large-scale, multi-species assessment: Anadromous salmonids in the Columbia River Basin. Ecol. Appl. 13(4): 964-989.

McKenzie, J.A. \& G.M. Clarke. 1988. Diazinon resistance, fluctuating asymmetry, and fitness in the Australian sheep blowfly. Genetics 120: 213-220.

McKenzie, J.A. \& K. O’Farrell. 1993. Modification of developmental instability and fitness: Malathion-resistance in the Australian sheep blowfly, Lucilia cuprina. Genetica 89: 67-76.

Møller, A.P. 1997. Developmental stability and fitness: a review. Am. Nat. 149: 916-932.

Møller, A.P. \& J.P. Swaddle. 1997. Asymmetry, Developmental Stability, and Evolution. Oxford University Press Inc. New York. 291 pp.

Nehlsen, W., J.E. Williams \& J.A. Lichatowich. 1991. Pacific salmon at the crossroads: Stocks at risk from California, Oregon, Idaho, and Washington. Fisheries 16: 4-21.

Neville, A.C. 1976. Animal Asymmetry. Edward Arnold Publishers Ltd., London.

Palmer, A.R. 1994. Fluctuating asymmetry: A primer. pp. 335-364. In: T.A. Markow (ed.) Developmental Instability: Its Origin and Evolutionary Implications, Kluwer Academic Publishers, Dordrecht, the Netherlands.

Palmer, A.R. \& C. Strobeck. 1992. Fluctuating Asymmetry as a measure of developmental stability: Implications of nonnormal distributions and power of statistical tests. Acta Zool Fennica 191: 57-72.
Palmer, A.R. \& C. Strobeck. 1986. Fluctuating asymmetry: Measurement, analysis and pattern. Annu. Rev. Ecol. Syst. 17: 391-421.

Perez-Tris, J., R. Carbonell \& J.L. Telleria. 2002. Parasites and the blackcap's tail: Implications for the evolution of feather ornaments. Biol. J. Linn. Soc. 76: 481-492.

Piper, R.G., L.E. McElwain, J.P. McCaren, L.G. Fowler \& J.R. Leonard. 1982. Fish Hatchery Management. U.S. Department of the Interior, Fish and Wildlife Service, Washington, D.C., $517 \mathrm{pp}$.

Polak, M. 2003. Introduction. pp. xix-xxiii. In: M. Polak (ed.). Developmental Instability Causes and Consequences. Oxford University Press, New York

Polak, M. 1994. Parasites increase fluctuating asymmetry of male Drosophila nigrospiraculla: Implication for sexual selection. pp. 257-268. In: T. Markow (ed.) Developmental Instability: Its Origins and Evolutionary Implications, Kluwer Academic Publishers, Dordrecht, the Netherlands.

Reisenbichler, R.R. \& S.P. Rubin. 1999. Genetic changes from artificial propagation of Pacific salmon affect the productivity and viability of supplemented populations. ICES J. Mar. Sci. 56: 459-466.

Rice, W.R. 1989. Analyzing tables of statistical tests. Evolution 43: 223-225.

Ricker, W.E. 1972. Hereditary and environmental factors affecting certain salmonid populations. pp. 19-160. In: R.C. Simon \& P.A. Larkin (ed.) The Stock Concept in Pacific Salmon, Macmillan Lectures in Fisheries, University of British Columbia, Vancouver, B.C.

Sokal, R.R. \& F.J. Rohlf. 1981. Biometry. W.H. Freeman \& Co., New York, 859 pp.

Soule, M.E. 1967. Phenetics of natural populations. II. Asymmetry and evolution in a lizard. Amer. Nat. 101: 142-159.

Smith, C.E. \& R.G. Piper. 1972. Pathological effects in formalintreated rainbow trout (Salmo gairdneri). J. Fish. Res. Board. 29: 328-329.

Taylor, E.B. 1991. A review of local adaptation in Salmonidae, with particular reference to Pacific and Atlantic salmon. Aquaculture 98: 185-207.

Ueno, H. 1994. Fluctuating asymmetry in relation to two fitness components, adult longevity and male mating success in a ladybird beetle, Harmonia axyridis (Coleoptera: Coccinellidae). Ecol. Entomol. 19: 87-88.

Valentine, D.W. \& M.E. Soule. 1973. Effect of p,p-DDT on developmental stability of pectoral fin rays in the grunion, Leuresthes tenuis. Fish. Bull. 71: 921-926.

Van Dongen, S. 1999. Accuracy and power in fluctuating asymmetry studies: Effects of sample size and number of within-subject repeats. J. Evol. Biol. 12: 547-550.

Van Valen, L. 1962. A study of fluctuating asymmetry. Evolution 16: $125-142$.

Vrijenhoek, R.C. \& S. Lerman. 1982. Heterozygosity and developmental stability under sexual and asexual breeding systems. Evolution 36: 768-776.

Waddington, C.H. 1940. Organisers \& Genes. Cambridge University Press, Cambridge, England, 160 pp.

Waddington, C.H. 1957. The Strategy of the Genes. George Allen \& Unwin, London. 
Waples, R.S. 1991. Genetic interactions between hatchery and wild salmonids: Lessons from the Pacific Northwest. Can. J. Fish. Aquat. Sci. 48(Suppl. 1): 124-133.

Waples, R.S. \& J. Drake. 2003. Risk/benefit considerations for marine stock enhancement: A Pacific salmon perspective. pp. 260-306. In: K.M. Leber, S. Kitada, T. Svåsand \& H.L. Blankenship (ed.) Proceedings of Second International Symposium on Stock Enhancement. Kobe, Japan, January 2002, Blackwell Publishing Ltd, Oxford, U.K.
Whitlock, M.C. \& K. Fowler. 1997. The instability of studies of instability. J. Evol. Biol. 10: 63-67.

Wilkins, N.P., E. Gosling, A. Curatolo, A. Linnane, C. Jordan \& H.P. Courtney. 1995. Fluctuating asymmetry in Atlantic salmon, European trout and their hybrids, including triploids. Aquaculture 137: 77-85.

Zakharov, V.M. 2003. Linking developmental stability and environmental stress; A whole organism approach. pp. 402-414. In: M. Polak (ed.) Developmental Instability Causes and Consequences. Oxford University Press, New York. 